【論 文】

UDC : 534.833
日本建築学会計画系論文報告集 第 410 号・1990 年 4 月 Journal of Archit. Plann. Environ. Engng, AIJ, No.410, April, 1990

\title{
付加質量の付いた有限膜の遮音特性 SOUND INSULATION CHARACTERISTICS OF FINITE RECTANGULAR MEMBRANE WITH ADDITIONAL WEIGHTS
}

\author{
橋本典久*; 桂 充宏**, 安岡 正 人***, 藤井弘 義**** \\ Norihisa HASHIMOTO, Mituhiro KATURA, Masahito YASUOKA and Hiroyosi HUJII
}

\begin{abstract}
Through experiments concerned with the transmission of sound under conditions of normal incidence of plane wave, it has been confirmed that attaching weights on a membrane improves the sound insulation ability in a frequency range from natural frequency of the whole membrane to that of the partial area divided by the additional weights. This mechanism is as follows:

The additional weights act on the membrane to form divided modal shapes with the same phase, and that modal shapes interfere with the normal mode of the whole membrane. As a secondary effect, the additional weights prevent high-order vibrations of the membrane. By these total effects, a great deal of attention of sound occurs and the transmission loss is over thirty or forty decibels in the most efficient case. This method is simple, light-weight, possible to tune, and effective in a lower frequency range and hence the authors think that this method has the possibility of developing into a useful one in the field of noise control.
\end{abstract}

Keywords : membrane, additional weight, sound insulation, lower frequency range

\section{1. 序}

音響分野における膜の研究は, 主に振動性状の評価が 興味の対象であり，かつ工学的により重要な板の振動に 対する数学的取り扱いの前段的な意味合いが強い。この 膜振動の基礎理論に関しては小平 ${ }^{11} の$ 書物に詳しい。実 用的な見地からの膜の研究としては，マイクロホンに関

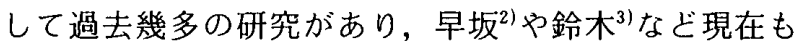
なお種々の条件下での研究が進められている。しかし， 騒音防止や音響調整といった面からの膜の利用に関して は，吸音材としての研究" $($ 散見されるものの，遮音材 としての研究はほとんど見当たらない。この理由として は，実用周波数帯域における制御の困難さもさることな がら，基本的には軽量さゆえの遮音性能の欠如にその原 因があることは明白であり，遮音材としては実用的な利 用価値がないというのが一般的な認識であった。当研究 ではこの逆の観点から膜を見直し，振動制御が可能であ る点あるいは軽量である点などの特質に着目し，遮音材 としての利用を計ろうというものである。

張力を与えて張った膜の遮音特性を実験的に検討して いる段階で，この膜に付加質量を取り付けて面的に分割 してやると, 低周波数領域での遮音性能が向上すること
が確認された。しかもこの性能は, 膜と付加質量を合わ せた場合の質量則による遮音量より遥かに大きく，また その効果の生じる周波数範囲もかなりの広帯域にわたる ものであった。図一1 はこの方法の模式図であるが，付 加質量を取り付けた膜（以下これを付加質量膜と呼ぶ） のこの効果は, 膜の大きさ, 面密度, 材料種別, 張力な どにより変化し，また付加質量の配置や数，質量の影響 により種々の変化を示すことがわかった。本報告では, まず付加質量膜の基本的な遮音特性と効果の呈示を行 い, 上記要因の変化により生じる遮音性能への影響を実
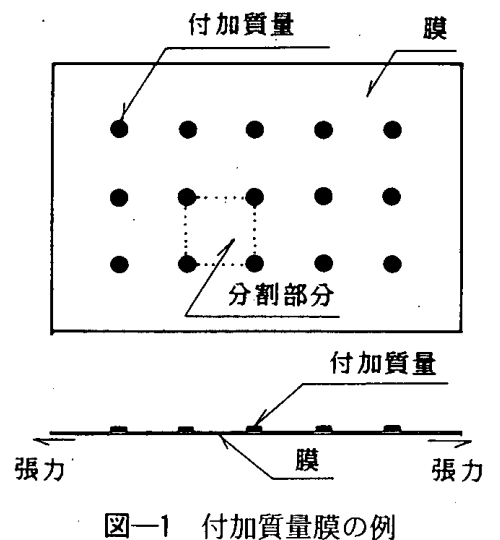

図一1 付加質量膜の例

\footnotetext{
当研究の一部は，平成元年度音響学会秋季研究発表会にて発表。

*. 鴻池組技術研究所 研究員

** 鴻池組技術研究所 研究員

*** 東京大学 教授. 工博

**** 東洋大学 講師
}

Konoike Construction Co. Ltd, reseach engineer Konoike Construction Co. Ltd, reseach engineer University of Tokyo, professor, Dr. of engineering Toyo university, lecturer 
験的に究明するとともに，低音域で遮音性能が向上する 機構を膜振動之音響放射に関する実験的・解析的考察に より明らかにしている。

\section{2. 付加質量膜の遮音効果に関する実験}

\section{1 実験方法および式験体}

遮音実験は図一 2 に示す簡易無響室内において実施し た。開口部の大きさは最大 $20 \mathrm{~cm} \times 30 \mathrm{~cm}$ であり, 平面 波垂直入射条件での実験となる。音源にはホワイトノイ ズを用い，音の入射側 $\left(P_{i}\right)$ と透過側 $\left(P_{r}\right)$ の 2 点にマイ クを設置して同時測定を行い, FFT 分析と多数回平均 を行った後に（1）式によりレベル差を算出した。

$$
\Delta L=\left(L_{i 1}-L_{r 1}\right)-\left(L_{i 0}-L_{r 0}\right)
$$

$L_{i 1}, L_{r 1}$ ：試験体が有る時の音圧スペクトルレベル $(\mathrm{dB})$

$L_{i 0}, L_{r 0}$ ：武験体が無い時の音圧スペクトルレベル $(\mathrm{dB})$

この実験方法により得られたレベル差を, 本論文では遮 音効果量と記すこととするが，これは基本的に垂直入射 時の音響透過損失に相当するものとなる5 。参考として アルミ板の測定結果を図一 3 に示したが, 有限板の遮音 特性を良く表しており, また值自体も垂直入射の音響透 過損失に良く一致しており妥当な結果となっている。

実験に用いた膜は市販の塩化ビニールシートであり， 厚さ $0.14 \mathrm{~mm}$ ，面密度 $0.256 \mathrm{~kg} / \mathrm{m}^{2}$ と薄いものである。

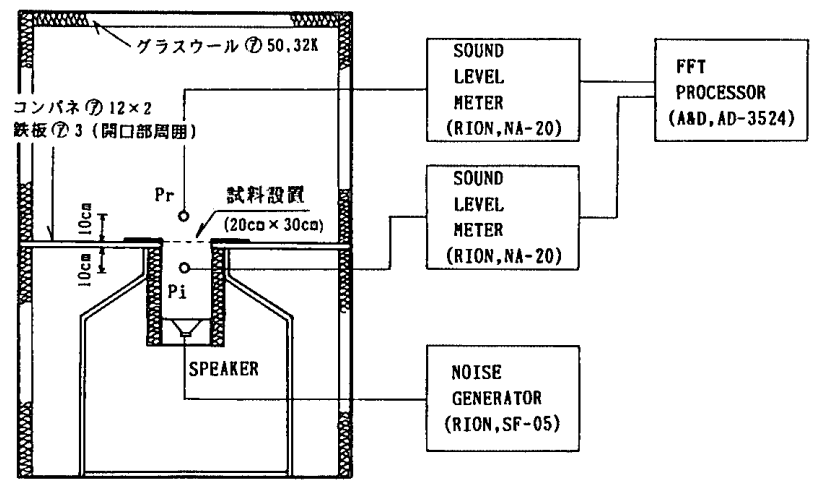

図一2 遮音実験の方法・機器構成

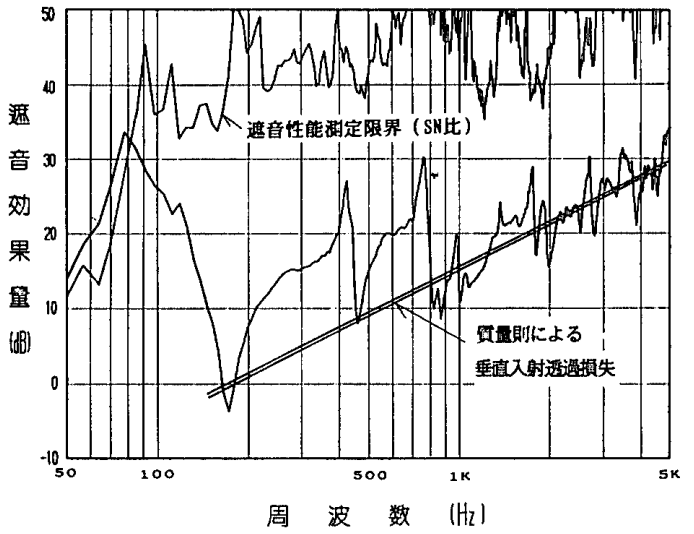

图一3 アルミ板の遮音効果測定例 (厚み $0.3 \mathrm{~mm}$, 大きさ $10 \mathrm{~cm} \times 15 \mathrm{~cm}$ )
膜の張力に関しては, 実験実施中は極力一定に保ったが, 経時的な緩和や張りむらのため，時間的あるいは面的に 若干の変化を生じている場合もある。

なお当報文においては，遮音機構究明のため，条件が 明確な平面波垂直入射条件での実験ならびに解析につい て述べているが，この他に残響室一残響室における拡散 入射時の遮音実験も一部行っており，この場合にも同様 の効果が得られることを確認している。

\section{2 付加質量膜に上る遮音効果の基本特性}

遮音実験により得られた付加質量膜の遮音性能につい て示す。図一4(a)，(b) は膜のみの場合および付加質量 膜の場合の遮音特性の測定結果である。図一4(a) の膜 だけの場合の結果においては，膜の大きさが有限である ことからその遮音特性は固有振動モードのピークを持 ち, 図中の $171 \mathrm{~Hz}$ は (長辺, 短辺) に関する $(1,1)$ モ一 ド， $288 \mathrm{~Hz}$ は $(3,1)$ モードの固有振動モードである。 この膜に付加質量が付くと，図一4(b) に示すように膜 全体の $(1,1)$ モ一ドの固有振動数は付加質量の質量の 影響により $105 \mathrm{~Hz}$ へと移行し，一方，新たに付加質量 により区切られた膜の部分 [分割部分] の固有振動数に よるピークが現れてくる $(354 \mathrm{~Hz}$ または $393 \mathrm{~Hz})$ 。この 2 つの固有振動数で挟まれた周波数範囲においては, 膜 のみの場合の反共振点での dipなどと比べて遥かに大き な遮音効果が得られ，当研究ではこの帯域での効果を対 象として “付加質量膜の遮音効果” あるい略して遮音効 果と呼ぶ。

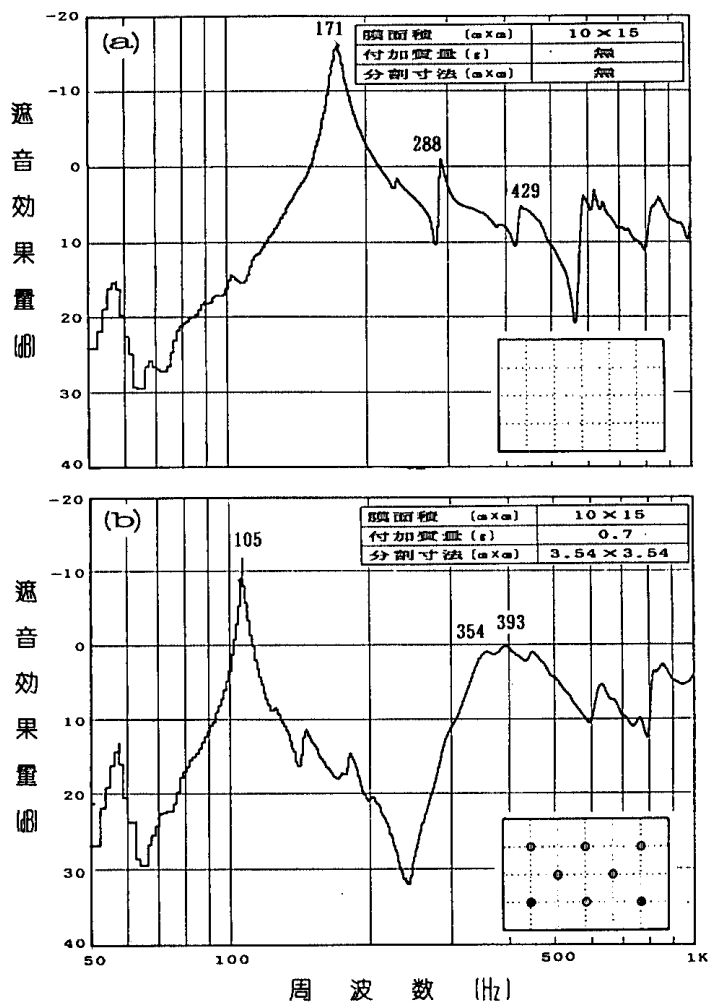

図一4 付加質量膜の遮音効果の基本特性 [(a) 膜のみの場合, (b) 付加質量膜の場合] 


\section{3 各種条件変化の遮音効果への影響}

この付加質量膜の遮音効果を規定すると考えられる膜 および付加質量の条件を抽出して，その影響を実験的に 究明した。測定条件および測定試験体の概要は図一5に 示すとおりである。まず図一6は膜の分割寸法を変化さ せた場合の結果である。分割を細かくするに応じて付加 質量の数が増すことになるため, 膜全体の 1 次の固有振 動数は徐々に低下し，分割部分の固有振動数はその寸法 が小さくなるため高周波数側に移行する。したがって遮 音効果の生じる周波数帯域は分割が細かくなるに応じて 広くなるが，遮音効果の大きさ自体はほとんど変化しな い。このような特性を示す理由は, 分割部分の固有振動 数から遮音効果の dip に至る傾きが分割が細かくなるに したがって緩くなってくるとともに，同時に膜全体の固 有振動数のピークが尖鋭でなくなってくるため，すなわ ち減衰が大きくなってくるためである。分割寸法の変化 に対するこれらの傾向は，膜の大きさを変えた場合の実 験においても同様の結果となっている。

膜の大きさ，分割寸法の条件は変えずに付加質量の質 量のみを $0.7 \mathrm{~g}, 1.4 \mathrm{~g}, 2.8 \mathrm{~g}$ と重くしていうた場合の 結果が図一7である。この場合には，付加質量の質量の

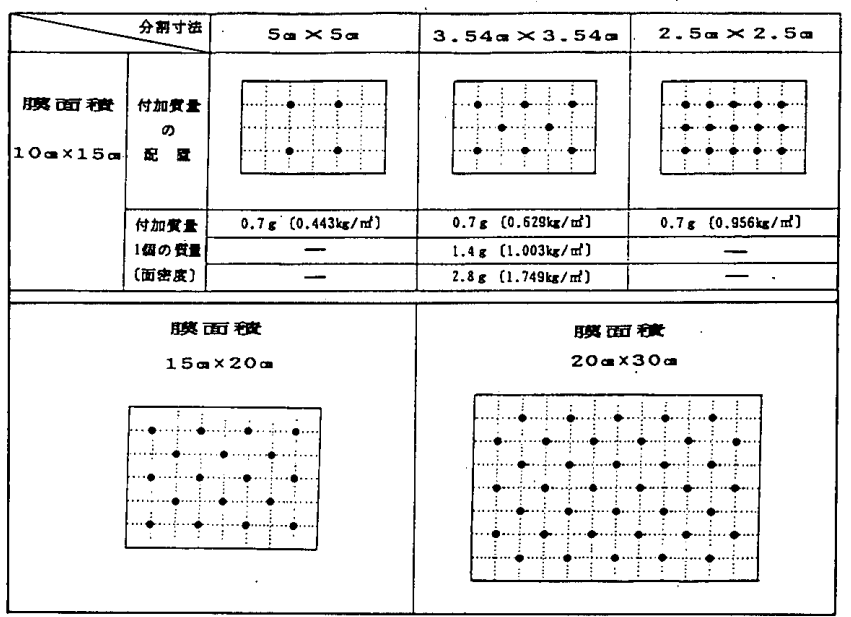

図一5 付加質量膜の測定条件と試験体

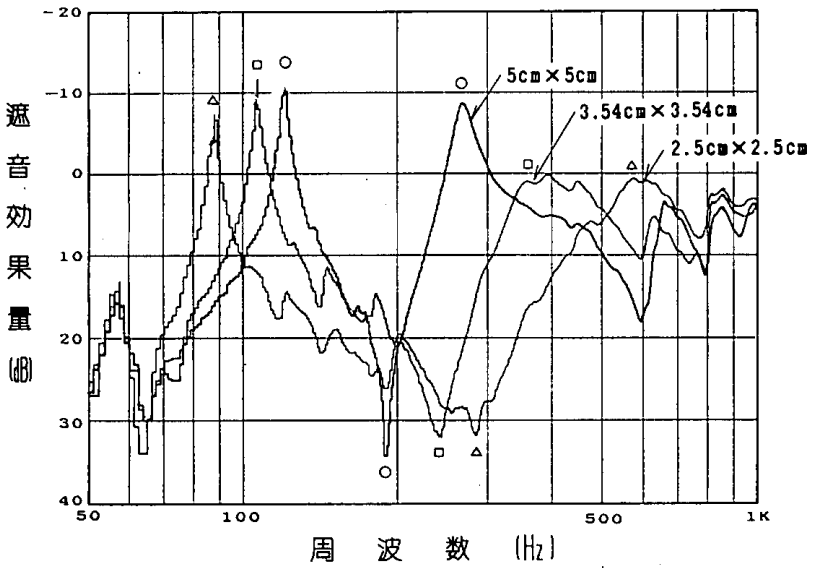

図一6 付加質量による分割寸法の変化の影響 （膜面積 $10 \mathrm{~cm} \times 15 \mathrm{~cm}$ ，付加質量 $0.7 \mathrm{~g}$ )
影響で膜全体の固有振動数は低音側に移行するが，分割 部分の固有振動数はほとんど変化しないため, 遮音効果 の周波数帯域は低周波数側に広がってゆくことになる。 またこの場合には分割寸法を変化させた場合とは異な り, 遮音効果は付加質量の質量の変化とともに増大して ゆく結果となる。分割部分の特性に関しては，付加質量 の質量の違いによりその部分の拘束の度合いが変化する ため，固有振動数がわずかに変化するとともに, dip へ の傾きが質量が大きくなるとともに緩くなる。そのため 遮音効果の dip 周波数位置は低音側に移動する形とな る。

膜の大きさを変えた時の結果の 1 例を図一 8 に示し た。この場合には張力の張りむらがあるためあまり明確 ではないが，これ以外の測定結果も含めて全般的に，膜 の大きさが大きくなると付加質量膜の遮音効果が減少す る傾向が見られた。

図一9には参考として張力がない場合の測定結果を示 した。膜だけの場合，付加質量が付いた場合の特性とも ほとんど平坦となっており，膜としての遮音特性は全く 見られなくなる。

以上より，平面波垂直入射条件での結果ではあるが，

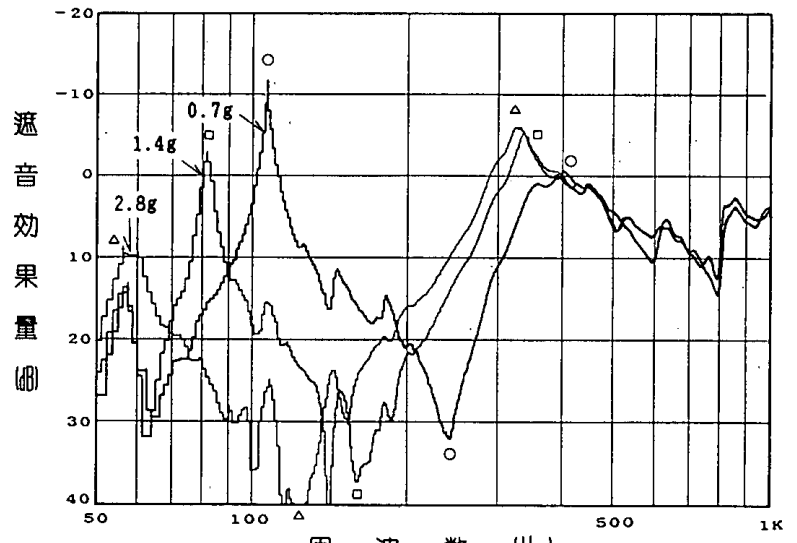

周 波 数 $\left|H_{2}\right|$

図一7 付加質量の質量変化による影響

(膜面積 $10 \mathrm{~cm} \times 15 \mathrm{~cm}$, 分割寸法 $3.54 \mathrm{~cm} \times 3.54 \mathrm{~cm}$ )

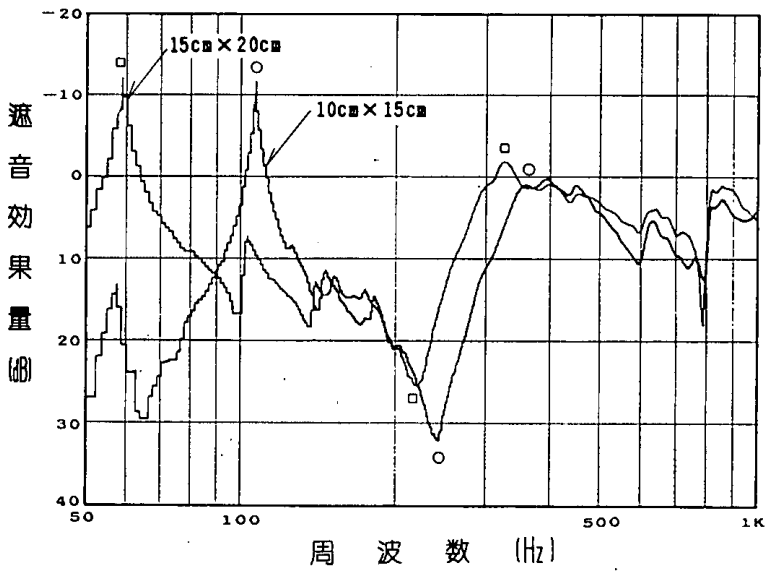

図一8 膜の大きさによる影響

(分割寸法 $3.54 \mathrm{~cm} \times 3.54 \mathrm{~cm}$, 付加質量 $0.7 \mathrm{~g}$ ) 
付加質量膜の遮音効果に関する基本的な特性を明確化す ることができた。また，これらの結果により，各種条件 による付加質量膜の遮音特性の変化を定性的に推定する ことも可能であると考える。

\section{3. 付加質量膜の遮音機構の究明}

前章で示された付加質量膜の遮音効果について，その 遮音機構の詳細を究明するため膜の振動性状および音響 放射性状に関して検討した結果を示す。

3.1 付加質量膜の振動モ一ド

図-10(a)，(b)，(c) は，膜の中央に付加質量が 1 個 付いた状態において，その付加質量の重さを順次重くし ていった時の遮音効果の測定結果である。これらの結果 において特徴的な点を挙げると次のようになる。付加質 量の重さを重くしてゆくとまず図一10(a) における膜の

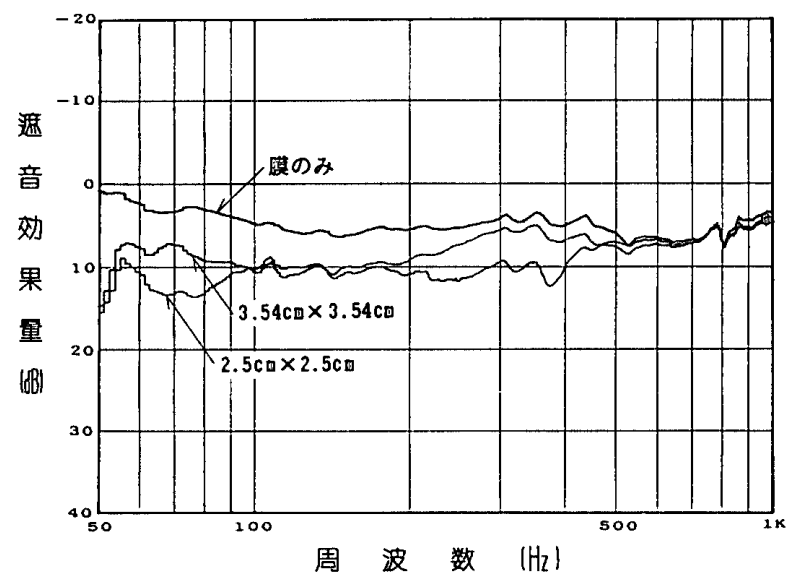

图一9 張力がない場合の膜の测定結果 （膜面積 $10 \mathrm{~cm} \times 15 \mathrm{~cm}$, 付加質量 $0.7 \mathrm{~g}$ )
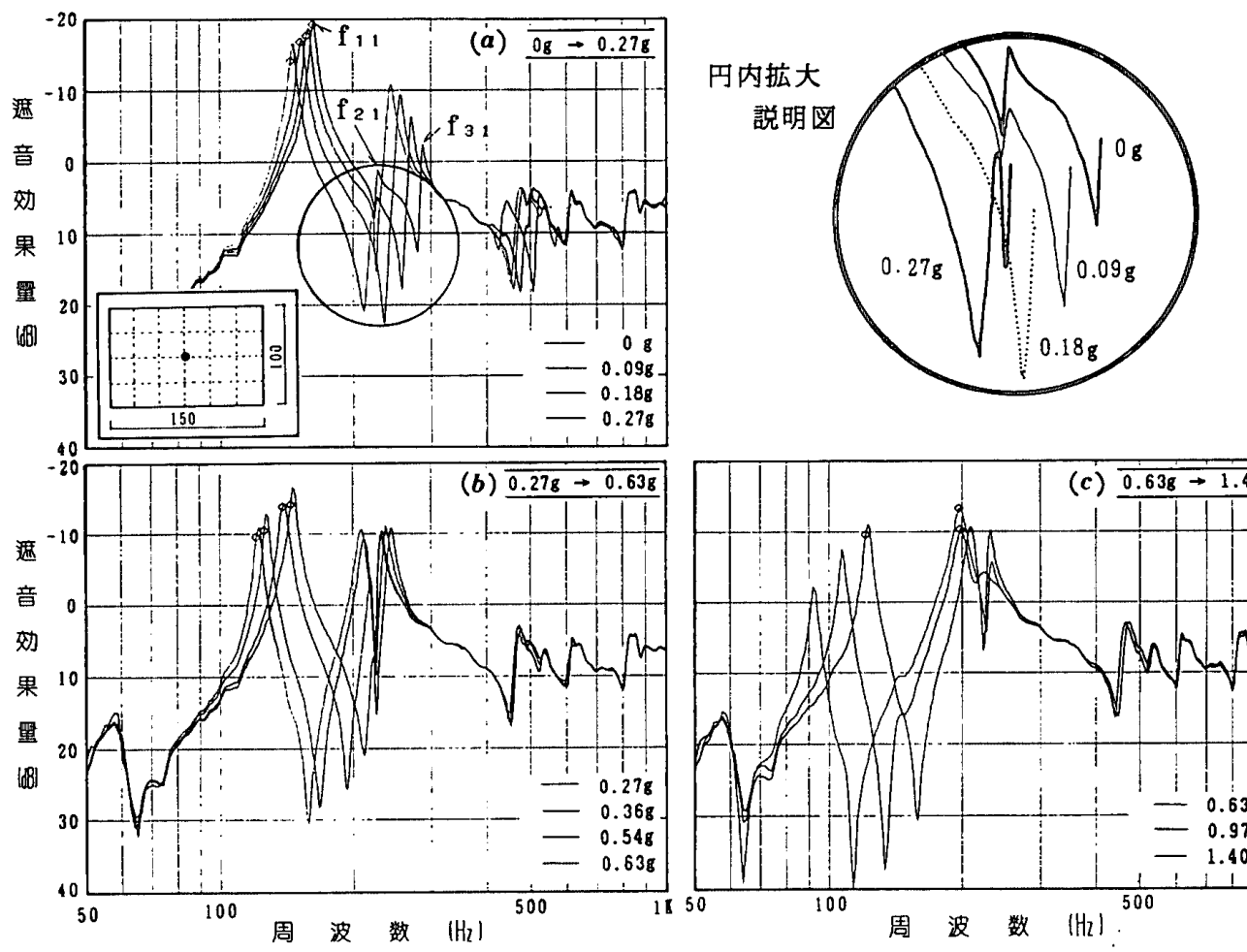

M 2

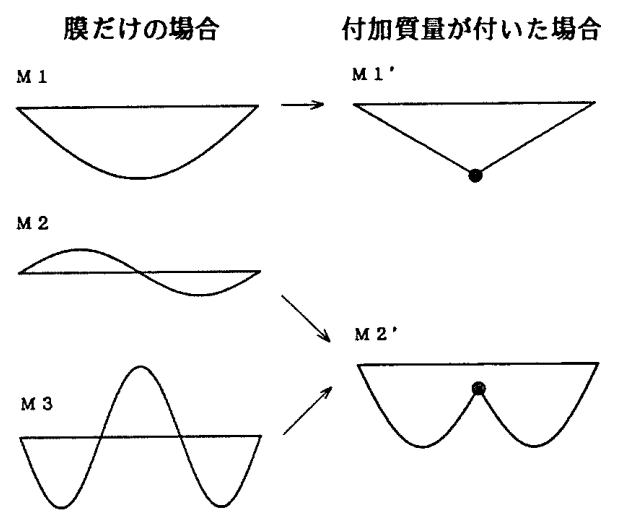

図一11 付加質量による膜の振動モード変化の推定図

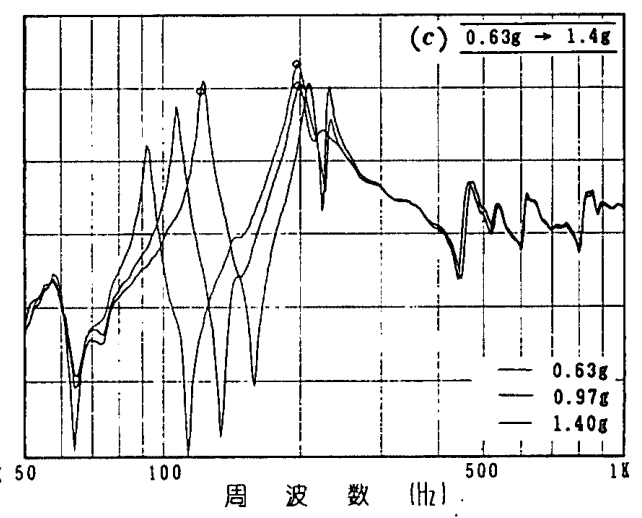

図一10 付加質量の重さを順次增していった時の遮音特性の変化

みの場合の $f_{21}$ のピークが徐々に小さくなり，0.18g で 一旦完全に消えた後に再びピークが現れ［円内拡大説明 図参照], このピークが再び大きくなり振動数が低下し てきた $f_{31}$ のピークと一つになり，分割部分のピークを 形造る。そして図一 10 (c) の $0.97 \mathrm{~g}$ 以上になると，こ の周波数はほとんど変化しなくなる。これらのスペクト ルの変化が生じる状況をを膜の振動モードとしてとらえ ると，図一11のような状態が考えられる。付加質量の 重さが軽い場合には振動モードがあまり変化せず，膜だ けの場合の $\mathrm{M} 1 \sim \mathrm{M} 3$ に近い形で振動しているが，付加 質量の重さが重くなるにしたがいM2，M3 のモードは M2'のモードに移行して一つのモードになるものと考 えられる。このモードはちょうど，付加質量により膜を 分割した形であり，またこれらの一連の変化により，付 加質量膜の遮音効果が膜全体の 1 次の固有振動数と分割 部分の固有振動数の間で生じていることは明らかであ 
る。なお図一 10 によれば付加質量による分割の効果が 明確に現れてくるのは約 $0.5 \mathrm{~g}$ であり, これは膜の面密 度で換算すると $2 \mathrm{~cm}^{2}$ 分の重さとなり, かなり軽量なも ので十分な効果が生じていることになる。

\section{2 モ一ド間の干渉効果}

付加質量膜の遮音効果は膜全体の固有振動数と分割部 分の固有振動数の間の周波数帯域で生じる。この帯域に 対する両振動モードの影響を，膜だけの場合と付加質量 膜の両方についての 1 次元モードに関するモデル計算を 用いて考察する。ただし，これはあくまで現象説明のた めの単純化した取り扱いであり, 実際の振動状態や音響 放射機構を記述したものではない。

いま膜だけの場合を考えて，1 次モードと 2 次モード の影響を仮に（2）式のように表す。

$$
\zeta(x)=(1-r) \sin \frac{\pi x}{a}+r \sin \frac{2 \pi x}{a} .
$$

$$
\text { ただし， } 0 \leqq r \leqq 1
$$

これに対し付加質量の膜の場合には, 図一11のモード を参考にして以下の 2 通りについて計算する。

$$
\begin{aligned}
& \zeta(x)=(1-r) \sin \frac{\pi x}{a}+r\left|\sin \frac{2 \pi x}{a}\right| \\
& \zeta(x)=(1-r) \sin \frac{\pi x}{a}-r\left|\sin \frac{2 \pi x}{a}\right|
\end{aligned}
$$

これらの 3 式について $r$ の変化に対する振動モードお よびモード全体についての実効値（rms）を算出したも のが図一12, 図一13である。この図一13 のモデル計算 結果から推測されるように，付加質量膜が膜だけの場合 より実効值が小さくなるためには，分割部分の振動モー ドが全体の膜の振動モードを打ち消すような干渉的な働 きがなくてはならないことになる。実際の現象は，振動 数や振幅, 減衰などの要因や音響放射条件が入ってくる
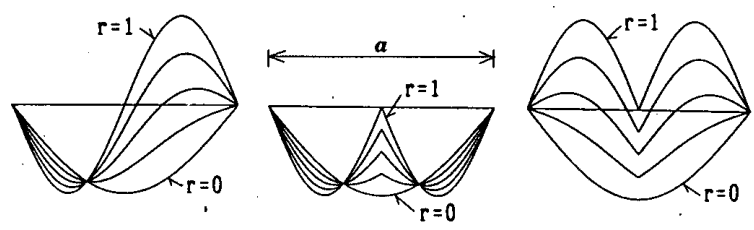

图一12 パラメーターrの変化による 1 次モードから 2 次モー ドへのモード変化（左より（2）式，（3）式，（4） 式の場合)

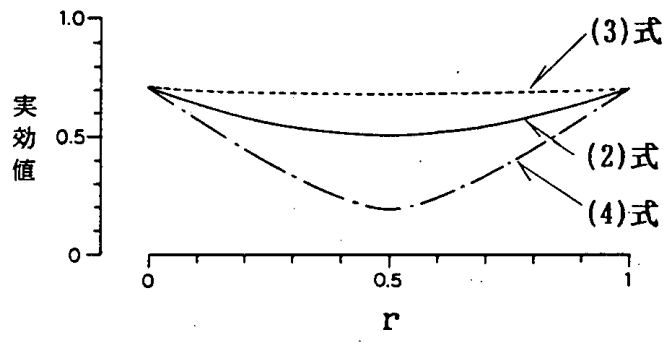

图一13 1 次モードから 2 次モードへのモード変化時の実効値 計算結果 (a)

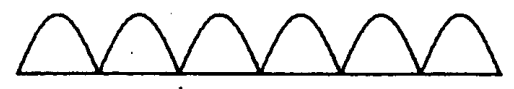

(b)

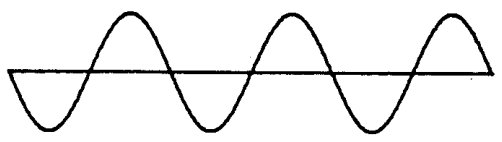

图一14 振動モードの比較 ( ( a ) 付加質量膜, (b) 膜のみの場合)

ためこのように単純ではないが，その基本的な機構とし てはここで示した形と同様なことが音響放射について成 立しているものと考えられる。このモード間の連成によ る干渉的な働きの存在は図一10(c) に示される鋭い dip の形成からも伺える。

3.3 分割モードの遮音特性

図一14 は, 膜のみの場合と付加質量膜の場合の高次 モードの比較図である。これらの振動数は共に等しくな る。付加質量膜のモード $(a)$ に関して, 振動モードの半 波長に相当する部分を一つの音源と見なすと, 音源間の 距離に比べて音の波長は遥かに長く，またすべての音源 が同位相で動くことになるから，これらの音源からの音 響放射においては指向性や音源間の干渉は生じず，その 遮音特性は一つの音源が単独に存在している場合の特性 と相似になる。一方，モード(b)の場合にはこのような 単純な形とはならず，各部からの位相干渉を考慮した膜 全体の特性としてとらえねばならない。以上のことから， 付加質量膜の遮音特性は次のようになる。付加質量膜の 分割部分の特性は, 膜のみの場合の遮音特性を膜の大き さが小さくなった分だけ高周波数側へシフトした特性と なり，また膜全体の特性は付加質量による質量増加分だ け低周波数側へシフトした形となる。付加質量膜全体の 特性はこれらが組み合わされたものとなり，両者の 1 次 の固有振動数間の周波数帯域においては, 先に示した干 渉的な働きにより付加質量膜の遮音効果が生じることに なる。図一4(b) の付加質量膜の基本特性はこのように 形造られていると考えられる。また副次的な効果ではあ るが，付加質量が離散的に取り付けられているため 1 次 モード以外の高次モード振動が出にくくなり, その帯域 の放射音が抑えられることも要因の一つとして挙げられ る。以上が付加質量膜の遮音効果の機構であり, 遮音特 性の決定要因であると考えられる。

\section{4. 遮音機構の解析的検証}

これまで考察した付加質量膜の遮音機構を検証する目 的で，この機構を解析的に表現して計算を実行し，その 結果が実測結果の傾向とよく対応し得るかどうかの検討 を行った。

ます最初に, 解析の基本となる膜のみの場合の音響透 過損失の計算方法について示した。次に，付加質量膜の 遮音特性は, 前章の遮音機構の検討結果をもとに以下の 方法により計算した。

1）付加質量により分割された部分の音響透過損失 
は，面積が小さくなった膜のみの状態として扱えること から，膜の音響透過損失計算方法をそのまま用いて，こ れを計算する。

2）付加質量の付いた膜全体に関する遮音特性は，付 加質量と膜の質量を均した均一な膜としてこれを取り扱 い，かつ高次モードの影響を除き 1 次モードのみを対象 とする。したがって，これも上記の計算方法に準じて計 算が可能である。

3）付加質量膜の遮音特性は，これら2つの遮音特性 を組み合わせ，かつ膜全体の固有振動数と分割部分の固 有振動数の間の帯域で，両固有モード間の連成による放 射音の打ち消し合いが生じているとしてこれを計算す る。

\section{1 平面波垂值入射時の膜の遮音計算}

付加質量膜の遮音特性評価の基本として, 実験条件と 同様に平面波垂直入射時の音響透過損失を計算する。入 射平面波の音王を $p_{i}$, 膜の透過側の膜面放射音王を $p_{r}$ とすると,この時の膜の変位は, 図-15の座標系に関 して,

$$
\begin{aligned}
\xi(x, y)= & \frac{1}{\gamma} \sum_{m} \sum_{n} \frac{1}{\Gamma_{m n}} \cdot \frac{\iint q\left(x^{\prime}, y^{\prime}\right) \phi_{m n}\left(x^{\prime}, y^{\prime}\right) d x^{\prime} d y^{\prime}}{\omega^{2}-\left(\omega_{m n}+i k_{m n}\right)^{2}} \\
& \cdot \phi_{m n}(x, y) e^{i \omega t} \ldots \ldots \ldots \ldots \ldots \ldots \ldots \ldots \ldots \ldots(5)
\end{aligned}
$$

となる ${ }^{6)}$ 。ここで, $q\left(x^{\prime}, y^{\prime}\right)$ は膜に対する加振力であり $2 p_{i}-2 p_{\tau}$ となり ${ }^{7)}, \omega$ は入射波の角周波数， $\omega_{m n}, k_{m n}$ は膜の $(m, n)$ モードの固有角周波数と制動係数であり， 各々

$$
\omega_{m n}=\pi \sqrt{\frac{g T}{\gamma}\left(\frac{m^{2}}{a^{2}}+\frac{n^{2}}{b^{2}}\right)}
$$

$T$ ：単位長さ当りの張力 $(\mathrm{kg} / \mathrm{m})$

$\gamma$ : 膜の面密度 $\left(\mathrm{kg} / \mathrm{m}^{2}\right)$

$$
k_{m n}=h_{m n} \omega
$$

$h_{m n}$ : 固有モードの減衰定数

である。また $\phi_{m n}$ は波動関数， $\Gamma_{m n}$ はその基準化因数で あり

$$
\begin{aligned}
& \phi_{m n}(x, y)=\sin \frac{m \pi x}{a} \sin \frac{n \pi y}{b} \cdots \\
& \Gamma_{m n}=\int_{0}^{b} \int_{0}^{a} \phi_{m n}^{2}(x, y) d x d y=\frac{a b}{4}
\end{aligned}
$$

と表される。ここで簡便のため, 加振力に関してのみ膜 面上の音纴を一定として取り扱うものとすると
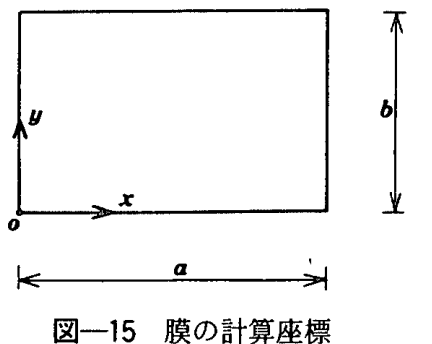

$$
\begin{aligned}
& \int_{0}^{b} \int_{0}^{a} 2\left(p_{i}-p_{r}\right) \phi_{m n}\left(x^{\prime}, y^{\prime}\right) d x^{\prime} d y^{\prime} \\
& =2\left(p_{i}-p_{\tau}\right) A_{m} A_{n}
\end{aligned}
$$

となる。この取り扱いは, 今回のように膜の寸法に比し て音の波長が長い低周波数域では十分に成立すると考え られる。これらの結果より膜の振動速度主は

$$
\begin{aligned}
\dot{\xi}(x, y)= & \frac{2 i \omega\left(p_{i}-p_{r}\right)}{\gamma} \sum_{m} \sum_{n} \frac{1}{\Gamma_{m n}} \\
& \cdot \frac{A_{m} A_{n} \phi_{m n}(x, y)}{\omega^{2}-\left(\omega_{m n}+i k_{m n}\right)^{2}} e^{i \omega t}
\end{aligned}
$$

となる。膜からの放射音による膜面上の音圧は，

$$
p_{r}(x, y)=\frac{i \omega \rho}{2 \pi} \int_{0}^{b} \int_{0}^{a} \frac{e^{\imath \omega t-k \eta}}{r} \cdot \dot{\xi}\left(x^{\prime}, y^{\prime}\right) d x^{\prime} d y^{\prime}
$$

$$
\text { ただし } r=\sqrt{\left(x-x^{\prime}\right)^{2}+\left(y-y^{\prime}\right)^{2}}
$$

であり，膜の放射パワーは，

$$
W_{r}=\frac{1}{2} \int_{0}^{b} \int_{0}^{a} p_{r}^{*}(x, y) \cdot \dot{\xi}(x, y) d x d y
$$

となる。 $\rho$ は空気の密度，*は共役複素数を表す。当計 算におけるこの放射パワーの計算は，膜面を仮想的に分 割しその代表点の音圧と振動速度により計算した。(13) 式に関しては周知のように

$$
\dot{\xi}^{*}\left(x^{\prime}, y^{\prime}\right) \dot{\xi}(x, y)=-\dot{\xi}\left(x^{\prime}, y^{\prime}\right) \dot{\xi}^{*}(x, y)
$$

なる関係があるから，これを考虑して放射音王の (12) 式を整理すると

$$
\begin{aligned}
p_{r}(x, y)= & -\frac{i \omega^{2} \rho\left(p_{i}-p_{r}\right)}{\pi \gamma} \sum_{m} \sum_{n}\left[\frac{1}{\Gamma_{m n}} \cdot \frac{A_{m} A_{n}}{\omega^{2}-\left(\omega_{m n}+i k_{m n}\right)^{2}}\right. \\
& \times \int_{0}^{b} \int_{0}^{a} \frac{\sin k r}{r} \sin \frac{m \pi x^{\prime}}{a} \\
& \left.\cdot \sin \frac{n \pi y^{\prime}}{b} d x^{\prime} d y^{\prime}\right] \ldots \ldots \ldots \ldots \ldots \ldots \cdots(15)
\end{aligned}
$$

となる。これより放射音圧 $p_{r}$ を求め，この $p_{r}$ を(11) 式に代入すれば膜面の振動速度 $\dot{\xi}$ も決定することがで きる。

膜の透過損失は, 入射パワー $W_{l}$ と放射パワー $W_{r} に$ より

$$
T L=10 \log \left(\frac{W_{r}}{W_{i}}\right)
$$

として求められる。ここで入射パワーは

$$
W_{i}=\frac{1}{2} \int_{0}^{b} \int_{0}^{a} \frac{\left|p_{i}\right|^{2}}{\rho c} d x d y=\frac{\left|p_{i}\right|^{2} a b}{2 \rho c}
$$

である。また（15）式の 2 重積分の計算に関しては，特 異点を除いて数值計算の精度を高めるため,

$$
\begin{aligned}
\frac{\sin k r}{r}= & \frac{k}{2 \pi} \int_{0}^{2 \pi} \int_{0}^{1} \cos \left\{k \sqrt{1-s^{2}}\left(x-x^{\prime}\right) \cos \theta\right\} \\
& \times \cos \left|k \sqrt{1-s^{2}}\left(y-y^{\prime}\right) \sin \theta\right| d s d \theta
\end{aligned}
$$


なる関係 ${ }^{8)}$ 用いて変換を行ったのち, Ledendre-Gauss の積分公式 (4 点公式) を用いて計算した。

\section{2 付加質量膜の遮音効果の計算}

分割部分の遮音特性は, 先に述べたように膜のみの場 合の上記の計算方法により求められる。ただし付加質量 による分割は 4 点のみの拘束となることから，（8）式 で与えられる四周を支持された振動モードとは異なり， 付加質量部分および四周部分で変位を生じている。その ためこの固有振動数は（6）式で与えられる值より小さ くなりここではこれを考慮して（6）式で与えられる 固有振動数の 0.6 倍として計算している。これは, 第 1 章の実験結果から求めた平均的值である。次に, 膜全体 の遮音特性は付加質量の総質量を膜面全体に均した均一 値と考えて計算する。ただし，この場合には 1 次モード のみが卓越するという特徴を表現するため，(11）式に 相当する掁動速度を

$$
\dot{\xi}(x, y)=\frac{2 i \omega\left(p_{t}-p_{\tau}\right)}{\gamma^{\prime}} \cdot \frac{A_{1} A_{1}^{\prime}}{\Gamma_{11}} \cdot \frac{\phi_{11}(x, y)}{\omega^{2}-\left(\omega_{11}+i k_{11}\right)^{2}} e^{i \omega t}
$$

$$
A_{1}=\frac{2 a}{\pi}, \quad A_{1}^{\prime}=\frac{2 b}{\pi}, \quad \Gamma_{11}=\frac{a b}{4}
$$

$\phi_{11}, \omega_{11}, k_{11}:(1,1)$ モ一ドの波動関数, 固有角周波 数および制動係数

とした。これを用いた放射音圧，放射パワーの計算手順 は分割部分の場合と全く同じである。

付加質量膜の全体の周波数特性について、は, 膜の振動 速度および放射音に関する厳密な解析は困難であるの で,ここでは遮音機構の検討結果を参照し, 上記で計算 された $2 つ の$ 遮音特性を組み合わせる形で，簡便的に放 射パワーに関する差をとって，

$$
W=\left|n W_{p}-W_{0}\right| \cdots
$$

として計算した。ここで $W_{\rho}$ は膜の分割部分について計

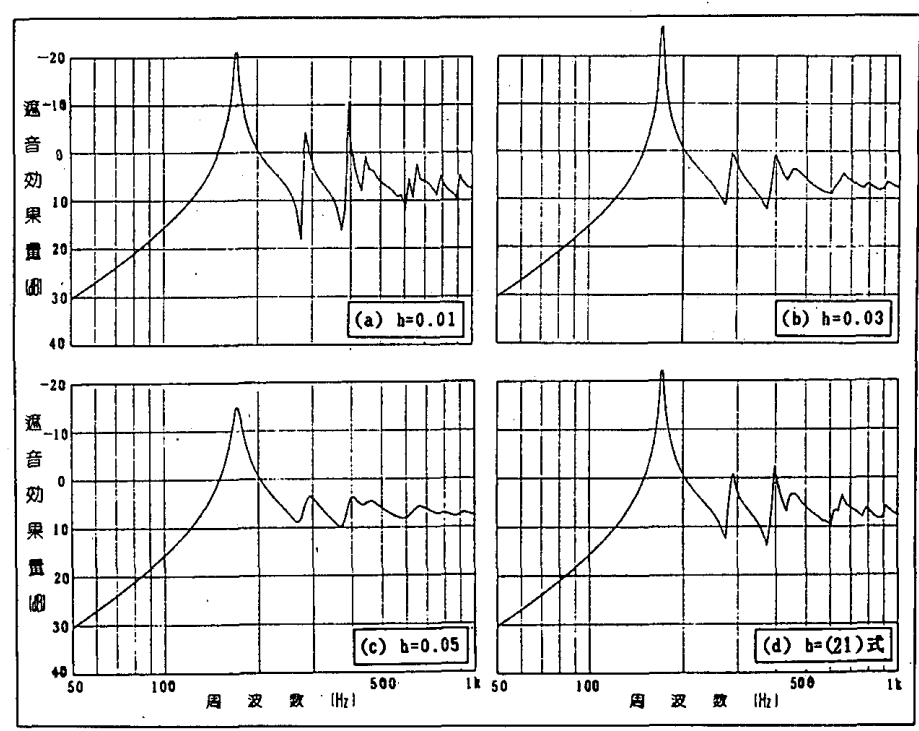

図一16 膜のみの場合の計算結果（振動减衰定数の変化）
算される放射パワー， $n$ はその分割総数， $W_{0}$ は膜全体 に関して計算した放射パワーである。なお分割部の固有 振動数以上の遮音特性は, 分割部の特性をそのまま用い ている。

\section{3 計算結果と実測結果の比較}

まず基本となる膜だけの場合の解析結果について示 す。解析条件は第 1 章の実測試験体の条件に基づき, 膜 面積 $10 \mathrm{~cm} \times 15 \mathrm{~cm}$, 面密度 $0.256 \mathrm{~kg} / \mathrm{m}^{2}$, 張力 21.2 $\mathrm{kg} / \mathrm{m}$ とした。図一16(a)～(d) は減衰定数を変化させ た場合の解析結果であり, 実測結果は既に示した図一4 (a) である。(a) （c) · は全周波数带域とも減衰定数一 定とし，その值を各々 $h=0.01,0.03,0.05$ とした場合 の結果であり，(d) は減衰定数の周波数特性を仮に

$$
h=5.14 / f+1.61 \times 10^{-5} f \text {. }
$$

として計算したものである。この值は $0.63 \mathrm{~g}$ の軽量ピッ クアップを膜に取り付け，衝撃法により振動減衰を測定 した結果を参考にしたものであり，膜に対するピック アップの重さやコードの影響を含むため正確なものとは 言えず，単なる設定值にすぎない。これら4ケースの結 果では, 全体的な特性として (b), (d) の結果が比較的 実測結果に近いものとなっている。第一共振点における ピーク值が実測に比べやや大きくなっているが，これは 減衰定数が明確でないことにあわせ，実測膜の張力に張 りむらがあるため実測のピークの方が小さくでているこ とが考えられる。なおこれと同様に, 実測值の高次モ一 ドの固有振動数は（6）式に与えられる理論値より小さ くなっており，ここでの計算においてはこれを考虑して （6）式加ら得られる高次振動数の値を 0.9 倍して用い ている。これら膜のみの場合の結果から，4.1で示した 計算方法はほぼ妥当であると言え，これを用いて以下の 付加質量膜の解析を行った。減衰定数の值は膜全体に関 しては（21）式の值, 分割部分に関しては全周波数域と も一率 0.03 として計算した。

図一17は, 膜の分割寸法を変化させた時の結 果である(実測結果は図一6)。計算結果の周波数 特性は実測結果の特性を良く表しており，特に遮

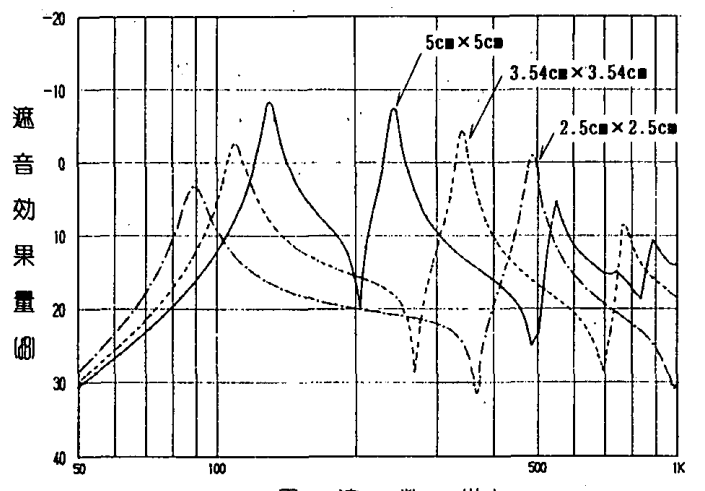

周 波 数 $\left(\mathrm{H}_{2}\right)$

図一17分割寸法の変化の影響（計算結果） （膜面積 $10 \mathrm{~cm} \times 15 \mathrm{~cm}$ ，付加質量 $0.7 \mathrm{~g}$ ) 


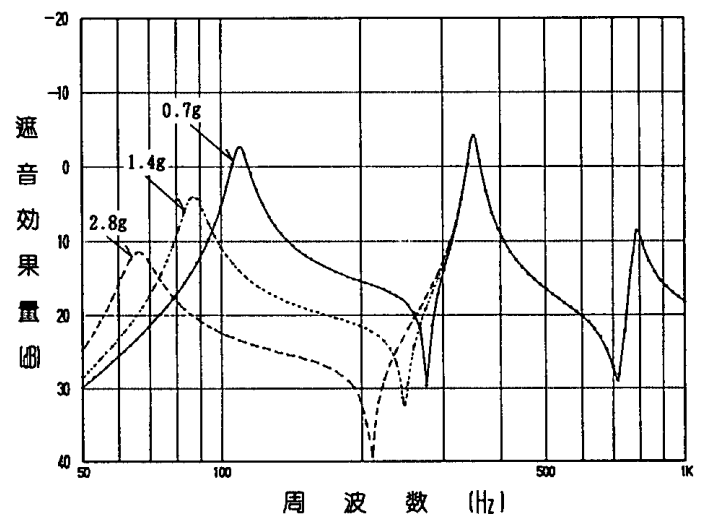

図一18 付加質量の質量変化の影㗽（計算結果）

(膜面積 $10 \mathrm{~cm} \times 15 \mathrm{~cm}$, 分割寸法 $3.54 \mathrm{~cm} \times 3.54 \mathrm{~cm}$ )

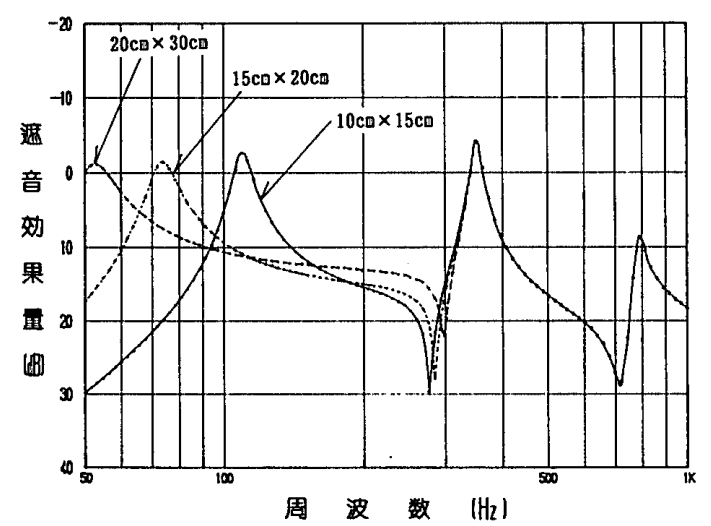

図一19膜の大きさによる影響（計算結果）

（分割寸法 $3.54 \mathrm{~cm} \times 3.54 \mathrm{~cm}$, 付加質量 $0.7 \mathrm{~g}$ )

音効果の dip 周波数位置の現れ方は良く一致している。 また值自体もほぼ妥当なものとなっている。図一18は 付加質量の質量のみを変化させた場合の結果（実測結果 は図一7）であるが，質量が増すことにより性能が向上 する様子が良く表されており，また dip 周波数位置の変 化も良く対応している。図一19は膜の大きさを変化さ せた時の結果（実測結果は図一8）である。膜の大きさ が大きくなると遮音効果が小さくなる傾向が見られる が, これには膜の減衰定数の周波数特性設定值の影響も 含まれ，また張力の差など実測結果の方の条件も明確で ないため厳密な比較は出来ない。

これらの結果において, 解析結果の傾向は実測結果と 良く対応しており，また遮音効果の値自体と全般的にほ ぼ近いものとなっている。したがって，解析的に検証し たこれらの内容からも第 3 章で示した付加質量膜の遮音 機構に関する考察はほぼ妥当なものであると言えよう。 なお解析結果と実測結果の差となって表れている主な点 は, 分割部分の固有振動数付近の特性によるものであり， これは膜と付加質量の連成的な㗢きによるものであると 考えられ，ここで示した簡便的な方法ではその表現に限 界がある。

5. 結 語

張力を与えて張った有限な膜に付加質量を取り付けた
場合の遮音特性を実験的に究明し，低周波数領域におい て生じる付加質量膜の遮音効果の機構を実験的および解 析的検討により明確化した。この効果は, 付加質量膜全 体の固有振動数と付加質量による分割部分の固有振動数 の間で生じることから, 数オクターブ程度の広帯域での 遮音効果も期待でき, また質量則の遮音機構とも全く異 なることから, 軽量であるにもかかわらず大きな遮音効 果を得ることができる。例えば図一7 の実験結果の付加 質量 $2.8 \mathrm{~g}$ の例では面密度 $1.8 \mathrm{~kg} / \mathrm{m}^{2}$ でありながら 125 $\mathrm{Hz}$ 近辺で $40 \mathrm{~dB}$ の遮音効果が得られている。ただし, 拡散入射条件での測定も一部実施してはいるが, 基本的 な部分は小試料を対象とした平面波垂直入射時の結果で あり, 解析的にもその条件に基礎を置いているため, よ り一般的な拡散入射条件での遮音特性の評価も今後検討 してゆく必要がある。実用的な観点から当方法を眺める と現状では対処すべき問題点が山積している点は否めな いが, 低周波数領域で大きな遮音性能が得られる可能性 があること，低減効果およびその周波数を自由にチュー ニングできること, あるいは軽量で簡易な構造とするこ とができることなど，騒音防止工法に適した特質を有し ている。騒音の制御・防止に関しては，低音域での改善 を図れば格段に性能が向上するものが多数あり、これら に関して質量則に基礎をおく従来の遮音工法とは異なっ た，新たな利用方法が可能ではないかと考える。

\section{謝 辞}

実験および研究遂行に協力頂いた東洋大学・上野研究 生（当時）および (株) 鸿池組・伝法研究所の諸氏に, ここに記して謝意を表します。

\section{参考文献}

1) 小平吉男 : 物理数学 - 第一巻, 現代工学社, pp. 236 431, 昭和 49 年

2) 早坂寿雄 : 円形振動膜の振動特性, 日本音響学会誌, Vol. 32, No. 11, pp. 693 702, 1976

3）鈴木久喜ほか 3 名：コンデンサーマイクロホンの膜振動 の数值シミュレーション, 日本音響学会騒音研究会資料, N 88-5-20, 1988

4）松井昌幸ほか 3 名：膜振動を利用した吸音器について, 日本音響学会講演論文集, pp. $77 \sim 78$, 昭和 39 年 10 月

5）坂田展甫, 大鶴 徹, 山岸豪敏: 円筒型遮音板の基礎的 特性解析, 日本建築学会計画系論文報告集, 第 351 号, pp. 1 10, 昭和 60 年 5 月

6) P. M. Morse : "Vibration and Sound", ASA, pp. 172 209, 1976

7）川井孝雄：一重板の遮音機構の解析，一円形板への平面 波垂直入射一，日本音響学会誌，Vol. 29, No. 4, pp. 186 $\sim 198,1973$

8）田中 洪：矩形中空壁の垂直入射波に対する透過損失の 解析, 日本音響学会誌, Vol. 31, No.7, pp. 441 448, 1975

(1989 年 8 月 10 日原稿受理, 1990 年 1 月 20 日採用決定) 